Kinestetik : Jurnal Ilmiah Pendidikan Jasmani

https://ejournal.unib.ac.id/index.php/kinestetik/index

\title{
SPORTS MOTIVATION SURVEY AND PHYSICAL ACTIVITY STUDENTS OF SPORT EDUCATION TEACHER TRAINING AND EDUCATION FACULTY FKIP MUHAMMADIYAH UNIVERSITY SURAKARTA
}

\author{
Gatot Jariono $^{1 *}$, Nur Subekti
}

${ }^{12}$ Sports Education, Teacher Training and Education Faculty, Universitas Muhammadiyah Surakarta, Sukoharjo, Indonesia

\section{Article Info}

Article History:

Received September 2020

Revised A September 2020

Accepted September 2020

Available online September 2020

\section{Keywords:}

motivation to exercise, physical activity, covid 19

\begin{abstract}
Abstrak
This study reveals the motivation to exercise and physical activity of UMS POR students in the COVID 19 new order. This study aims to explore the perceptions, strategies, and challenges of UMS POR students in the COVID 19 new order in having the motivation to exercise and perform physical activities during the Covid-19 pandemic. This case study uses quantitative and qualitative methods. Quantitative data using questionnaires and qualitative data obtained through interactive interviews using google forms. Quantitative data were analyzed using descriptive statistics of frequencies through Excel Microsoft 2013 and qualitative data were analyzed through interactive thematic data analysis. The results showed that (i) the sports motivation of UMS POR students in the COVID 19 new order was in a good category or $61.21 \%$, (ii) The physical activity of UMS POR students in the COVID 19 new order was in a good category or was $71.03 \%$. This study recommends that the more frequent physical activity students maintain their physical quality, this must be balanced with sports motivation that is qualified in the COVID 19 new order.
\end{abstract}

Corresponding address: Jln. Gayam No. 2 Karangasem, Jawa Tengah

Email :gj969@ums.ac.id
ISSN 2685-6514 (online)

ISSN 2477-331X (print)

DOI : $10.33369 / \mathrm{jk} . v 4 \mathrm{i} 2.12449$ 


\section{INTRODUCTION}

In new order era, it limits a person to do physical activity outside the home, in this case someone lacks motivation to exercise, and limits his daily physical activity. Basically, the motivation to exercise and physical activity can be done individually to maintain physical fitness. Basically, doing daily physical activities does not require a large space or place to do this. Doing physical activity requires exercise motivation, because doing physical activity is easier and more practical.

Currently the world is faced with an outbreak of the Covid-19 virus which has claimed many lives regardless of various backgrounds, social status, education, occupation, and no longer recognizes and takes into account skin color, ethnicity or ethnicity, race, even religion. all become one color and close ranks to fight the plague that swept the world.

Corona virus infection is called COVID-19 (Corona Virus Disease 2019) and was first discovered in the city of Wuhan, China at the end of December 2019. This virus is spreading very quickly and massively and has spread throughout the world including Indonesia. This makes several countries implement policies to impose lockdowns withclose all access in and out of their respective territoriesin order to prevent the spread of Covid-19. All corners of Indonesia have implemented a Large-Scale Social
Restriction (PSBB) policy and finally a new normal or new life order is implemented for physical activity provided that they maintain health protocols imposed by the government to suppress the spread of this virus. Efforts to avoid the corona virus are to stay away from crowds, social distance, increase immunity by doing sports activities.

Physical activity is a series of movements deliberately to improve physical fitness so that harmony and harmony are formed for the formation of a healthy and fit body, thus for the successful implementation of this task it is necessary to have a match between the requirements that must be met, namely anatomical and physiological in nature to the type and intensity of physical tasks. and motivation to carry out sports activities that must be carried out.

Motivation is an impetus that arises from within and from outside a person to carry out daily activities either without encouragement from other people or encouragement from others to carry out their activities. This is in line with Slameto (2003: 170), Walgito (2003: 220) Dimyati and Mudjiono (2002: 80) Hamalik (2005: 106), Hamzah B Uno (2010: 66), and Gunarsa (2008: 53) experts. This suggests that motivation is a change in energy within and from outside a person which is characterized by a feeling of reaction to achieve certain goals. Motivation contains desires, hopes, needs, goals, objectives and incentives. This condition is what activates, moves, 
channels, and directs the attitudes and behavior of individual learning. From the motivation to do sports activities, then arises from someone to do physical activity. Physical activity is a daily activity carried out by a person to maintain body fitness. This is in line with the opinion of Irianto (2000: 46), Faturrohman and Sutikno (2020: 19), Rivai and Murni (2009: 732) someone who performs physical activity with the type of exercise and intensity that has met the requirements, as well as the length of exercise with a frequency that is enough every week, will be able to obtain and maintain physical fitness.

Physical fitness is doing daily activities without feeling tired. This is in line with the opinion of Mutohir and Maksum (2007: 51), Mukholid (2007: 34), Wahjoedi (2003: 58), the Indonesian Health Ministry (2009: 9), and Giriwijoyo (2007: 43) some experts argue that physical fitness is a very important aspect of physical fitness as a whole, which in turn will give a person the ability to lead a productive life and be able to adapt to any proper physical load. Physical fitness refers to the ability and physical ability of a person to carry out his daily tasks with enthusiasm effectively and efficiently for a relatively long time without causing significant fatigue, and still has spare energy to carry out other activities.

But on the other hand, to carry out sports activities in this new era, you must follow health protocols, so that someone in carrying out their daily activities can avoid the impact of Covid 19. To do sports activities to improve physical fitness, it does not have to be done in open places such as fields but can be done indoors such as in a fitness center or done at home (stay at home). In accordance with these circumstances, the researcher intends to conduct a survey of the interest in sports and physical activity carried out by students during the Covid 19 pandemic and in the current new order.

\section{METHODS}

The method used in this research is survey research using qualitative and quantitative approaches. This research was conducted from July to August 2020. Participants [this is formatted as Heading Level 2].

This research was conducted in Sukoharjo with the research sample being all students of the sports education study program, Muhammadiyah University of Surakarta. With a total sample of 214 people who had filled out a questionnaire via google form.

\section{Sampling Procedures}

The sampling procedure was purposive sampling. Proposive sampling is an alternative, because the researcher considers the sample who has filled out a form via google form by considering the student's ability, one of which is having an internet quota. In this study, researchers conducted a survey with the help of google form through the link: https://docs.google.com/forms/d/1hfyoG Gz0msPt8Ybh43a2O4geUdzBlL9Xc13y nduFY8/edit 
This research requires consideration on the grounds of the student's ability to take the time to fill out the google form online This online costs money. So the researcher spends on the sample only those who are able to fill out the form and have an internal quota as the sample.

\section{Materials and Apparatus}

The data collection technique used several techniques, namely 1) The interview method was conducted intensively with informants to obtain the information needed in this study. Interviews were conducted in two ways, namely open and closed interviews. Open interviews are meant to dig deeper into the analysis of the motivation for sports and physical activity carried out by students during the Covid 19 pandemic and in the current new order. Meanwhile, a closed interview is to confirm the research data; and 2) the questionnaire method is distributed via google form online to students of the sports education study program to obtain quantitative data.

\section{Procedures}

The procedure in this study consisted of three stages, namely (1) the first stage the researcher categorized the supporting and unsupportive data with the focus in this study. Then the researcher examines the relationship between the data and field notes so that the data or information that has been obtained in the field can be known; (2) the second stage of the research pays attention to the data obtained, either in the form of direct statements or indirect conclusions related to the problem of this research; and (3) finding the validity of the data through triangulation.

\section{Design or Data Analysis}

This research uses a quantitative research approach and a qualitative approach. Meanwhile, data analysis was carried out by examining the data obtained from distributing questionnaires and interviews. Therefore, the data analysis process uses qualitative and quantitative approaches, the data analysis process starts with data reduction, data display, and data verification, while the explanation of the data analysis technique can be described as follows:

1) Data reduction refers to the process of selecting raw data that occurs in the field when data collection takes place through written field notes through distributing questionnaires about exercise motivation and physical activity to UMS POR students. Then categorize the data obtained in both qualitative and quantitative forms. The data is then analyzed using the descriptive statistical frequency test. Quantitative data were analyzed using frequency descriptive statistics through Microsoft Excel 2013, and qualitative data were analyzed through interactive thematic data analysis

2) Display data is a step where the researcher collects information that is structured to be described by drawing conclusions by taking action in this study;

3) Data verification is done by drawing conclusions from the results of this study. 


\section{RESULT}

1. The gender of the sample

The sex of the sample is more than half male. This shows that the male sample is more than the female sample, Figure 1 below describes a detailed description of the gender background of the sample in this study;

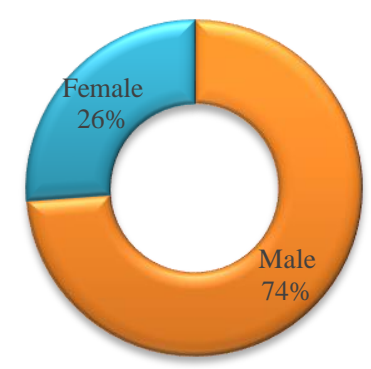

Figure 1. Gender of the Sample

The description of the sex of the sample shows that there are more male samples than female samples in the process of filling out the questionnaire. Among the 158 samples, $73.83 \%$ of them took the time to fill out questionnaires online, and $26.17 \%$ were samples of women who took the time to fill out questionnaires online. The sample is dominated by male students. Thus it can be concluded that physical activity and sports motivation are dominated by male samples, male samples assume that physical activity and sports motivation are in accordance with their needs.

\section{Situation analysis}

Motivation to exercise and physical activity are like sides of a coin that need each other, without motivation to exercise, it is impossible to do physical activity regularly and vice versa, physical activity is not accompanied by motivation to exercise, so a person is always lazy to do movement activities. From the situation analysis about motivation to exercise and physical activity in the
COVID 19 new order, it can be described in Figure 2 below

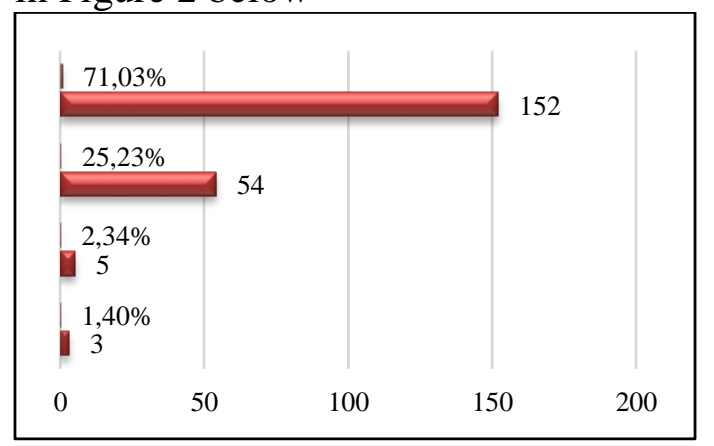

Figure 2. Analysis of the motivational situation exercise and physical activity

Situation analysis of the motivation to exercise and physical activity of sports education students in the new Covid 19 regime.More than half (71.03\%) of the sample from the survey agreed that in the COVID-19 pandemic situation, they always have motivation to exercise and and do physical activity by maintaining health protocols, $25,23 \%$ of them are in the occasional category, $2.34 \%$ of the sample are in the rare statement obtaining a percentage value of $1.40 \%$. Interestingly, only $1.40 \%$ of the sample never did physical activity and did not have the motivation to exercise to maintain a better physical condition or chose to stay at home during the COVID 19 pandemic. Figure 2 shows that most of the samples in this study were sample of men to do physical activity.

Related of exercise motivation and physical activity during this pandemic was supported by the interviews results with samples by telephone lines. The interview results with the sample "I am more enthusiastic about maintaining a better physical condition" (interview with Alif Khorouman Abidin, Thursday 27 August 2020). Thus motivation is a 
psychological condition that encourages the supporter community to do something

\section{Benefits of motivation to exercise and} physical activity

Based on the study results, there are three categories of benefits from physical activity and motivation to exercise: very beneficial, beneficial, and limited benefits (see Figure 3). Analysis of the motivation to exercise and physical activity of sports education students in the COVID 19 new order

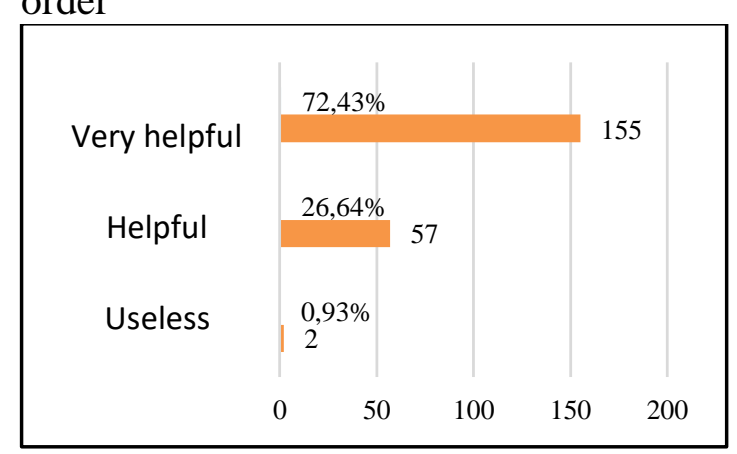

Figure 3. Benefits of exercise

Motivation survey and physical activity

Figure 3 shows the benefits of motivation survey to exercise and physical activity of sports education students in COVID 19 new order to help them regulate self-control of students to always maintain physical fitness with a feeling of pleasure in training and always trying to improve the quality for success, Always trying to outperform others / self-confidence, Enjoys getting compliments on what he does, Establishing a harmonious relationship between friends, Training with getting attention of friends and coaches / Standards of excellence, Helping parents garden / selling, or other professions. Doing sports activities (football, volleyball, badminton, and others, as well as doing sports activities (cycling, rock climbing, running / jogging and others. The benefits resulting from exercise motivation and physical activity can be described as follows:

1) The motivation to exercise UMS POR students in the COVID 19 new order is in a very good category, this is evidenced by a questionnaire that has been distributed via google form from 214 samples, it is known that 131 samples are very agreeable and get a percentage value of $61.21 \%$, and a score. The lowest was 1 sample who answered strongly disagree with a percentage value of $0.47 \%$. Thus it can be concluded that the results of the response strongly agree to get the highest score, this proves that the motivation to exercise sports education students is in a good category. Furthermore, from the results of the descriptive analysis of the frequency, the following is presented the data on the motivation to exercise of UMS POR Students in COVID 19 new order on following histogram form:

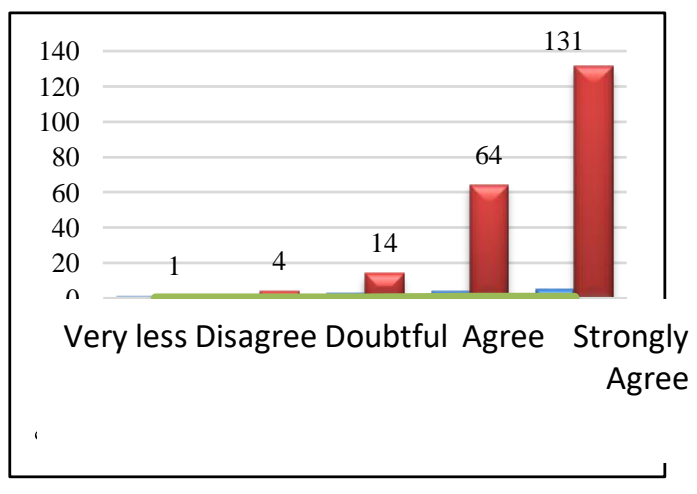

Figure 4. Histogram of the score of exercise motivation data

2) The physical activity of UMS POR students in the COVID 19 new order is in a good category, this is from a questionnaire that has been distributed via google questionnaire form from 214 samples, it is known that 152 samples are always in the 
statement and get a percentage value of $71.03 \%$, and the lowest score is found. 3 samples are in the statement never get a percentage value of $1.40 \%$. Thus it can be concluded that the results of the response always get the highest score, this proves that the physical activity of the UMS POR Students in the COVID 19 new order is in a good category. Furthermore, from the results of the descriptive frequency analysis, the following is presented the physical activity data of UMS POR Students in the COVID

19 new order in the following histogram form:

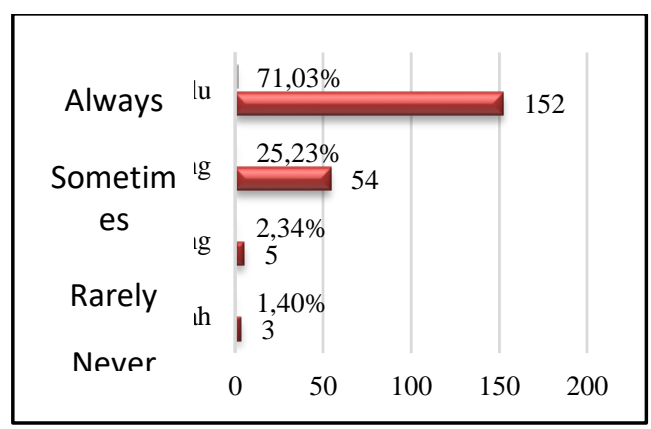

Figure 5. Histogram of data on scores of physical activity results of UMS POR Students in the new COVID 19 setting

The exercise motivation benefits survey and physical activity of sports education students in COVID 19 new order in terms of knowledge, skills, abilities, and motivation. Knowledge as the basis of truth that students must understand in maintaining their motivation to exercise and carry out physical activity for sports education students in COVID 19 new order; Skills are the ability of students to formulate goals, strategies, sympathy and empathy to control their physical fitness; Ability is the capacity of students to carry out various physical activities to keep the body healthy; and motivation is a psychological condition that encourages students to do something. In doing physical activities, motivation is needed,

4. The impact of the survey on exercise motivation and physical activity

The impact of survey on exercise motivation and physical activity of sports education students on the COVID 19 new order has categories, namely strongly agree, agree, doubt, disagree, and strongly disagree. The results of survey can be seen in the following histogram.

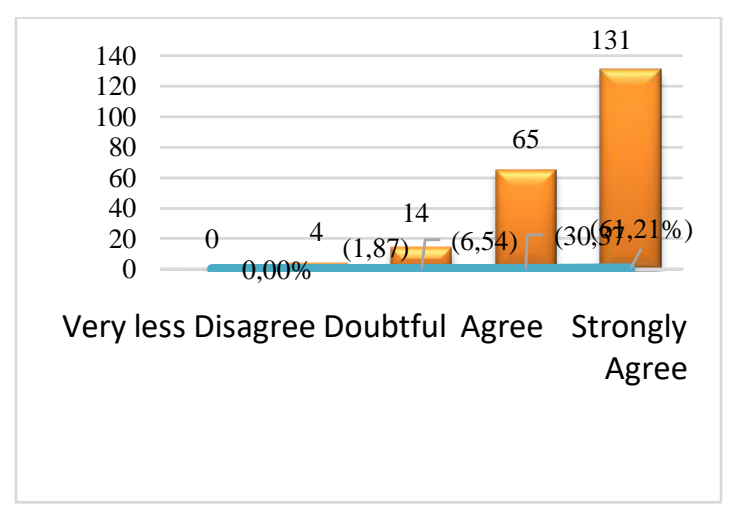

Figure 6. The impact of the exercise motivation survey and physical activity

Figure 6 below shows that there is a strong tendency where students in doing physical activities are always accompanied by motivation to carry out daily activities both in the surrounding environment and in the surrounding environment. Figure 6 illustrates that there are no students who believe that the exercise motivation survey and physical activity have a negative impact on students. The existence of a survey activity motivation to exercise and physical activity for students has a positive impact by understanding the importance of doing physical activity during a pandemic so that the body remains in shape and applying it in their 
daily lives, especially in keeping the body healthy.

5. Motivational challenges for sports and physical activity

Even though the students stated a positive impact on the motivational behavior of sports and physical activity of sports education students in the COVID 19 new order, they still face some challenges. And one of obstacles in doing physical activity is the massive spread of COVID 19. The description of understanding impact motivation to exercise and physical activity of students in the COVID 19 new order can be seen in the following histogram:

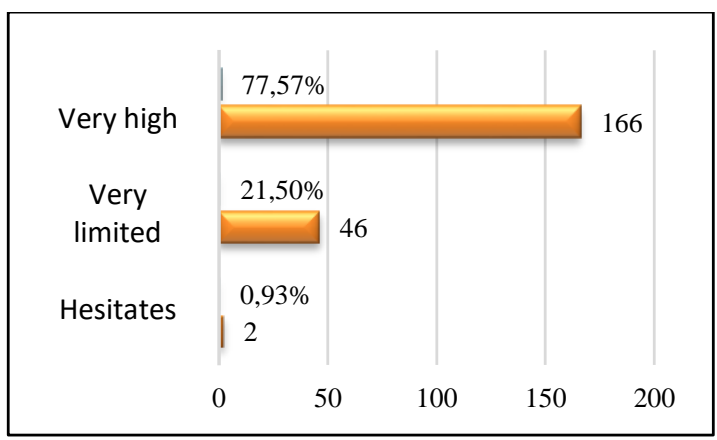

Figure 7. Survey challenges of motivation to exercise and physical activity

Based on Figure 7, the motivation survey to exercise and physical activity to students in the COVID 19 new order is the lack of awareness of the surrounding community about the dangers of spreading COVID 19 by complying with health protocols. These results are evidenced by a questionnaire that has been distributed from 150 samples, it is known that 166 or $77.57 \%$ of the samples are in a very high statement of understanding and the lowest score is in the very limited understanding category, and there are 2 samples who are in a statement of doubt obtaining a percentage value of $0.93 \%$. From these results it can be concluded that the challenges faced in this millennial era are very high, the last few months, there has been an interesting phenomenon in the danger of COVID 19 spread, namely that the public still ignores health protocols, especially in the challenges realm, motivation to exercise and physical activity, which is very interesting to study further in subsequent studies.

\section{DISCUSSION}

Based on data obtained in research on the motivation analysis to exercise and physical activity of UMS POR students in the COVID 19 new order, it is in a good category. Described on each indicator and sub-indicator statement in the percentage value $(\%)$ of questionnaire statement of the motivation to exercise and physical activity of the UMS POR students in the COVID 19 new order, from each indicator having a happy feeling in training and always trying to improve the quality for success, always trying to outperform others / self-confidence, enjoy getting praise for what he does, forging a harmonious relationship between friends, training with hope of getting the attention of friends and coaches/ excellence standards, helping parents with gardening/ selling, or other professions, do sports activities (football, volleyball, badminton, etc., as well perform sports activities (cycling, rock climbing, running/ jogging and other sobtained a percentage value of $61.21 \%$ and $71.03 \%$. The cumulative value of presentation can be calculated with an average value of $66.12 \%$ or in the good category. The statement in this good category is supported by the interpretation criteria of Riduwan's score (2013: 18) at an interval of $61 \%-80 \%$ in good category or by $66.12 \%$. Thus, this 
proves that the motivation to exercise and physical activity of POR UMS students in the COVID 19 new order has a positive impact on doing one's activities.

The motivation to exercise and physical activity of UMS POR students in the COVID 19 new order shows that the phenomenology of the COVID 19 pandemic in exercise motivation and physical activity is influenced by motivation both from within and outside of a person in doing physical activity. Blegur and Mae (2018) argue that motivation is an internal energy force that determines all aspects of individual behavior. This also affects how individuals think, feel, and interact with other individuals. This is in line with the opinion of Slathia, Singh, and Dar (2015). In sports themselves, athletes need motivational interventions for the training and competition process, even motivation is generally accepted as an important prerequisite for delivering athletes to fulfill their potential and performance. Motivation and sports performance play an important role, because the level of physical stress increases as the level of competition increases, the desire to achieve success and exercise is an obvious one.

This is in line with the results of Hadi's (2020) research that exercise is one of the physical activities that must be done during COVID 19 pandemic. The community must remain active even though they are working and studying from home. Social distancing and work from home tend to make a person have a sedentary lifestyle, studies show that a sedentary lifestyle can reduce immunity, thereby increasing the risk of viral infection (Association of sports specialists, 2020).

\section{CONCLUSION}

In accordance with the results and discussion of the research above, a conclusion can be drawn that: (i) the sports motivation of UMS POR students in the COVID 19 new order is in a good category or is $61.21 \%$, (ii) the physical activity of UMS POR Students in the new COVID order 19 in good category or $71.03 \%$.

\section{ACKNOWLEDGEMENT}

This research is an individual lecturer grant research funded by the Muhammadiyah University of Surakarta with the number PID-1633 for the 20202021 budget year.

\section{REFERENCES}

Blegur, J dan Mae R.M. 2018. Motivasi berolahraga atlet atletik dan Tinju. Jurnal Keolahragaan, 6 (1) 29-37

Dimyati dan Mudjiono. (2002). Belajar dan Pembelajaran. Jakarta: Rineka Cipta

Faturrohman, Pupuh dan Sutikno, M. Sobry, 2010. Strategi Belajar Mengajar, Melalui Penanaman Konsep Umum \& Konsep Islami, Bandung: Refika Aditama

Giriwijoyo Santoso H.Y.S. dan Sidik, Zafar, Dikdik (2007). Ilmu Faal Olahraga (Fisiologi Olahraga), Fungsi Tubuh Manusia pada Olahraga untuk Kesehatan dan Untuk Prestasi, Edisi. 7 , UPI Bandung,

Gunarsa, Singgih, D, (2008). Psikologi Olahraga Prestasi. Jakarta: Pbk Gunung Mulia

Hadi, Faisal Kusuma, 2020. Aktivitas olahraga bersepeda masyarakat di Kabupaten Malang Pada Masa Pandemi Covid 19. Sport Science \& Education Journal, 1 (2) 28-36

Hamalik, Oemar. 2005. Perencanaan Pengajaran Berdasarkan Pendekatan. Sistem. Jakarta: PT Bumi Aksara. 
Irianto, Djoko Pekik (2000). Pendidikan Kebugaran Jasmani yang Efektif dan. Aman. Yogyakarta: Lukman Offset

Mukholid, Agus, (2007). Pendidikan Jasmani Olahraga \& Kesehatan, Sesuai Standar Sma Kelas Xi Isi 2006, Surakarta: Yudistira,

Mutohir, Toho Cholik Dan Ali Maksum, (2007). Sport Development Index, Alternatif Baru Mengukur Kemajuan Pembangunan Bidang Keolahragaan, Konsep, Metodologi Dan Aplikasi, Jakarta: Indeks

Ridwan dan Akdon, (2013). Rumus dan Data dalam Analisis Statistika, Untuk Administrasi Pendidikan, Bisnis, Pemerintahan, Sosial, Kebijkan, Ekonomi, Hukum, Manajemen dan Kesehatan. Bandung: Alfabeta

Rivai, Veithzal dan Murni, Sylviana, (2009). Education Management, Analisis Teori dan Praktik, Jakarta: RajaGrafindo Persada.

Runar Vilhjalmsson And Gudrun Kristjansdottir, 2003.Gender Differences In Physical Activity In Older Children And Adolescents: The Central Role Of Organized Sport, 56 Social Science

Saleh, M. S., \& Malinta, S. S. (2020). SURVEI MINAT BELAJAR SISWA DALAM MENGIKUTI PEMBELAJARAN PENDIDIKAN JASMANI DI SMPN 30 MAKASSAR. Kinestetik: Jurnal Ilmiah Pendidikan Jasmani, 4(1), 55-62.

Sardiman, (2011). Interaksi \& Motivasi Belajar Mengajar, Jakarta: Rajagrafindopersada

Slameto. (2003). Belajar dan Faktor-faktor yang mempengaruhinya. Jakarta: Rineka Cipta.

Slathia, R., Singh, H., \& Dar, H.A. (2015) Motivation among male and female cricketplayers of Jammu division: A comparativstudy. International Journal in Physical \&Applied Science, 2(4), 5356.

Suryabrata, 2011. Psikologi Pendidikan (Jakarta: Raja Grafondo Persada
Uno, B. Hamzah, (2010). Teori Motivasi \& Pengukurannya, Analisis Di Bidang Pendidikan, Jakarta: Bumi Aksara.

Wahjoedi, Profil Kebugaran Siswa Sekolah Dasar Di Denpasar Bali Jurnal Iptekor Olahraga Vol. 5 No. 1 Januari 2003. Jakarta: Direktorat Olahraga Departemen Pendidikan, 2003. 